\title{
Identification of Correlation Between Poverty and Challenging Behavior at Secondary School Level in Pakistan
}

\author{
Muhammad Nasir Khan \\ Research Associate, Department of Education, International Islamic University Islamabad, Pakistan \\ Email: nasiriiu786@gmail.com
}

Doi:10.5901/mjss.2015.v6n3s1p394

Abstract

Poverty has a dominant influence on behavior of individuals. Challenging behavior is a worldwide problem and is mostly observed in the third world countries because of lack of basic needs. Study has been conducted to identify the correlation of poverty and challenging behavior in secondary school students in Pakistan. The study will be significant for researchers, policy makers, curriculum developers and NGOs working on education sector in Pakistan. Chi square and percentage has been used in data analysis.

\section{Statement of the Problem}

Poverty is always on going to affect the behavior of the students. In the developing countries like Pakistan, India, Bangladesh etc, such behavior is rapidly promoting in the students because of lack of financial instability of parents. Developed countries like United Sates of America, United Kingdom and Australia had worked on the role of poverty in promoting challenging behavior of the students but in Pakistan this study required attention. Therefore, the researcher has decided to work on this topic.

\section{Significance of the Study}

The study is significant to researcher, educational psychologists, behaviorists, parents and teachers. It carries inherent benefits to policy makers, society and for the NGO's working on the role of poverty in promoting challenging behavior in $9^{\text {th }}$ class students. There are very little efforts to study the nature and causes of challenging behavior of the students in Pakistan. This study will surely prove significant to overcome the challenging behavior of the secondary school students in Pakistan.

\section{Research Design}

The Convergent Parallel Design is used as a tool of research. This is a type of mixed method. In the convergent parallel design the researchers:

1. Collects quantitative and qualitative data alongside

2. Analyzes the two data sets separately

3. Mixes the two databases by merging the results during interpretation. (Creswell, 2013)

\section{Research Questions}

1. Whether poverty and behavior of $9^{\text {th }}$ class students are correlated with each other?

2. What are effects of poverty on the behavior of $9^{\text {th }}$ class students?

3. How poverty is promoting challenging behavior in $9^{\text {th }}$ class students?

\section{Literature Review}

"Poverty is the worst form of violence", said Gandhi. "If Pakistan wants to escape poverty, it needs to move past the rhetoric of increases in tax-to-GDP ratios and 'elimination' of corruption/terrorism. As the Planning Commission's 
"Framework for Economic Growth" rightly argues, Pakistan has to change its 'software' of economic development. It needs institutional reforms in civil service and the legal and judicial systems. It also needs a complete replacement of the old extractive bureaucratic institutional structures set in place by the British colonists with inclusive institutions" (Tribune 2013).

Male (2003), in research article, "Challenging behaviour: the perceptions of teachers of children and young people with severe learning disabilities" significantly notes challenging behaviour as: "Culturally abnormal behaviour(s) of such intensity, frequency or duration that the physical safety of the person or others is likely to be placed in serious jeopardy or behaviour which is likely to seriously limit or deny access to and use of ordinary community facilities" (Emerson, 1995, pp. 4-5). Dunber (2004) in article, "Best Practices in Classroom Management" describes that there is an equal impact of poverty on students' achievement as well as on their behavior.

Population of study: The study has been conducted on public sector secondary schools in urban areas of District Rawalpindi. Head teachers, teachers and parents of the $9^{\text {th }}$ class students were population of the study.

Sample of study:10 public sector secondary schools were selected from total number of public sector secondary schools belonging to urban areas of district Rawalpindi as sample of the study. 04 teachers were selected from each school (Gay, 1996).

Table 1: Sample of the study (Teachers \& Head Teachers)

\begin{tabular}{ccccc}
\hline Name of District & No. of Public Sector Secondary Schools & No. of Head Teachers & No. of Teachers teaching to 9 $9^{\text {th }}$ class Total \\
\hline Rawalpindi (urban ) & 10 & 10 & 40 & 50 \\
\hline
\end{tabular}

Table 2: Sample of the study (Parents of gth $^{\text {class students) }}$

\begin{tabular}{cc}
\hline Name of District & Total \\
\hline Rawalpindi (urban ) & 50 \\
\hline
\end{tabular}

\section{Research Instruments}

As the study was descriptive in nature therefore four questionnaires were used to collect data from teachers and head teachers and students of public sectors secondary schools in District Rawalpindi as well as interviews were conducted from parents of $9^{\text {th }}$ class students .Questionnaire was concerning role of poverty and challenging behavior in students. Head teachers and the most experienced teachers teaching to gth $^{\text {th }}$ class were request for the opinion regarding questions. Researcher developed these questionnaires by using five-point Likert scale on the basis of literature, related studies and under the guidance of supervisor.

\section{Procedure of Identification of $9^{\text {th }}$ Class Students with Challenging Behavior}

The selected sample of teachers teaching to $9^{\text {th }}$ class was asked for the identification of one student with challenging behavior from their respective classes. The teachers were briefed about the nature and characteristics of challenging behavior. The teachers identified the students with challenging behavior.

\section{Interview of Parents of the $9^{\text {th }}$ Class Students with Challenging Behavior}

The parents of the identified students with challenging behavior were approached through their sons. A structured interview was conducted from the parents of the students.

\section{Content Validity Ratio}

Lawshe (1975) proposed that each of the subject matter expert raters (SMEs) on the judging panel respond to the following question for each item: "Is the skill or knowledge measured by this item 'essential,' 'useful, but not essential,' or 'not necessary' to the performance of the construct?".Lawshe developed a formula termed the content validity ratio:

$C V R=($ ne $-N / 2) /(N / 2)$

$\mathrm{CVR}=$ content validity ratio,

ne = number of SME panelists indicating "essential", 
$\mathrm{N}=$ total number of SME panelists.

http://statforall.blogspot.com/2009/05/content-validity.html, retrieved on10/10/2013 AY 8:30

After literature review, content validity ratio of the concerned content was identified. 10 head teachers of public sector secondary schools (urban) were requested for the content validity ratio.

Table 3: Content validity ratio of questionnaire reading poverty and challenging behavior in $9^{\text {th }}$ class students.

\begin{tabular}{|c|c|c|}
\hline \multicolumn{2}{|c|}{$\begin{array}{l}\text { Questions regarding poverty and challenging behavior in } 9^{\text {th }} \text { class } \\
\text { students. }\end{array}$} & \multirow{2}{*}{$\begin{array}{c}\text { CVR= content validity ratio, Formula for CVR } \\
\text { CVR = (ne }-N / 2) /(N / 2) \text { where ne = number of SME panelists } \\
\text { indicating "essential", } N=\text { total number of SME panelists. } \\
0.8\end{array}$} \\
\hline 1. & Poverty affects behavior of students & \\
\hline 2. & Poverty is promoting challenging behavior & 0.9 \\
\hline 3. & Poverty is promoting irresponsibility in the students & 0.7 \\
\hline 4. & Poverty is promoting authoritative attitude in the students & 1.0 \\
\hline 5. & Poverty is promoting disappointment in the students & 0.7 \\
\hline 6. & Poverty is promoting loneliness in the students & 0.8 \\
\hline 7. & Poverty is promoting theft in the students & 1.0 \\
\hline 8. & Poverty is promoting drug addiction in the students & 0.9 \\
\hline 9. & Poverty is promoting cheating in the students & 1.0 \\
\hline 10. & Poverty is promoting hurting others in the students & 0.9 \\
\hline 11. & Poverty is promoting self-hurt in the students & 0.9 \\
\hline & Poverty is promoting misconduct in the students & 1.0 \\
\hline
\end{tabular}

\section{Data Collection and Analysis}

Data was collected personally through visits of public sector secondary school in urban areas of Rawalpindi. The teachers and head teachers were request for their opinion about the questions regarding poverty and challenging behavior of $9^{\text {th }}$ class students. The data was analyzed through chi square and percentage to meet the objectives of the study.

Table 1.1: Poverty affects behavior of students

\begin{tabular}{cccccccc}
\hline & SA & A & UD & DA & SD & Total & $X^{2}$ \\
\hline Responses & 38 & 12 & - & - & - & 50 & $108.8^{*}$ \\
Percentage & 76 & 24 & - & - & - & 100 & \\
\hline
\end{tabular}

* Significance $\mathrm{df}=4$ Table value $\chi^{2}$ at 0.05 level $=9.488$

Table 1.1 shows that the calculated $x^{2}$ value was found to be 108.8 , which is greater than the table value at 0.05 level. Hence, the statement is accepted.

Table 1.2: Poverty is promoting challenging behavior

\begin{tabular}{cccccccc}
\hline & SA & A & UD & DA & SD & Total & $X^{2}$ \\
\hline Responses & 40 & 10 & - & - & - & 50 & \multirow{2}{*}{$120^{*}$} \\
Percentage & 80 & 20 & - & - & - & 100 & \\
\hline
\end{tabular}

* Significance $\mathrm{df}=4$ Table value $\mathrm{x} 2$ at0.05 level $=9.488$

Table 1.2 shows that the calculated $x^{2}$ value was found to be 120 , which is greater than the table value at 0.05 level. Hence, the statement is accepted.

Table 1.3: Poverty is promoting irresponsibility in the students

\begin{tabular}{cccccccc}
\hline & SA & A & UD & DA & SD & Total & $X^{2}$ \\
\hline Responses & 12 & 38 & - & - & - & 50 & \multirow{2}{*}{$108.8^{\star}$} \\
Percentage & 24 & 76 & - & - & - & 100 & \\
\hline
\end{tabular}

* Significance $\mathrm{df}=4$ Table value $\mathrm{X}^{2}$ at 0.05 level $=9.488$ 
Table 1.3 shows that the calculated $x^{2}$ value was found to be 108.8 , which is greater than the table value at 0.05 level. Hence, the statement is accepted.

Table 1.4: Poverty is promoting authoritative attitude in the students

\begin{tabular}{cccccccc}
\hline & SA & A & UD & DA & SD & Total & $X^{2}$ \\
\hline Responses & 05 & 45 & - & - & - & 50 & \multirow{2}{*}{$155^{\star}$} \\
Percentage & 10 & 90 & - & - & - & 100 & \\
\hline
\end{tabular}

* Significance $\mathrm{df}=4$ Table value $\mathrm{X}^{2}$ at 0.05 level $=9.488$

Table 1.4 shows that the calculated $X^{2}$ value was found to be 155 , which is greater than the table value at 0.05 level. Hence, the statement is accepted.

Table 1.5: Poverty is promoting disappointment in the students

\begin{tabular}{cccccccc}
\hline & SA & A & UD & DA & SD & Total & $X^{2}$ \\
\hline Responses & 10 & 40 & - & - & - & 50 & $120^{*}$ \\
Percentage & 20 & 80 & - & - & - & 100 & \\
\hline
\end{tabular}

* Significance $\mathrm{df}=4$ Table value $\chi^{2}$ at 0.05 level $=9.488$

Table 1.5 shows that the calculated $x^{2}$ value was found to be 120 , which is greater than the table value at 0.05 level. Hence, the statement is accepted.

Table 1.6: Poverty is promoting loneliness in the students

\begin{tabular}{cccccccc}
\hline & SA & A & UD & DA & SD & Total & $X^{2}$ \\
\hline Responses & 20 & 30 & - & - & - & 50 & 80 \\
Percentage & 40 & 60 & - & - & - & 100 & \\
\hline
\end{tabular}

* Significance $\mathrm{df}=4$ Table value $\mathrm{X}^{2}$ at 0.05 level $=9.488$

Table 1.6 shows that the calculated $x^{2}$ value was found to be 80 , which is greater than the table value at 0.05 level. Hence, the statement is accepted.

Table 1.7: Poverty is promoting theft in the students

\begin{tabular}{cccccccc}
\hline & SA & A & UD & DA & SD & Total & x2 \\
\hline Responses & 41 & 09 & - & - & - & 50 & \multirow{2}{*}{$126.2^{*}$} \\
Percentage & 82 & 18 & - & - & - & 100 & \\
\hline * Significance df= 4 Table value $\chi^{2}$ at 0.05 level=9.488 & & & &
\end{tabular}

Table 1.7 shows that the calculated $X^{2}$ value was found to be 126.2 which is greater than the table value at 0.05 level. Hence, the statement is accepted.

Table 1.8: Poverty is promoting drug addiction in the students

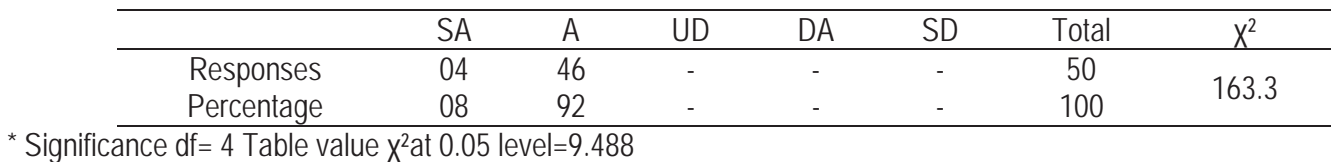

* Significance $\mathrm{df}=4$ Table value $\chi^{2}$ at 0.05 level $=9.488$

Table 1.8 shows that the calculated $x^{2}$ value was found to be 163.2 , which is greater than the table value at 0.05 level. Hence, the statement is accepted.

Table 1.9: Poverty is promoting cheating in the students

\begin{tabular}{cccccccc}
\hline & SA & A & UD & DA & SD & Total & $X^{2}$ \\
\hline Responses & 02 & 48 & - & - & - & 50 & \multirow{2}{*}{$180.8^{*}$} \\
Percentage & 04 & 96 & - & - & - & 100 & \\
\hline
\end{tabular}

* Significance $\mathrm{df}=4$ Table value $\chi^{2}$ at 0.05 level $=9.488$ 
Table 1.9 shows that the calculated $x^{2}$ value was found to be180.8, which is greater than the table value at 0.05 level. Hence, the statement is accepted.

Table 1.10: Poverty is promoting hurting others in the students

\begin{tabular}{cccccccc}
\hline & SA & A & UD & DA & SD & Total & $X^{2}$ \\
\hline Responses & 09 & 41 & - & - & - & 50 & \multirow{2}{*}{$126.2^{\star}$} \\
Percentage & 18 & 82 & - & - & - & 100 & \\
\hline
\end{tabular}

* Significance $\mathrm{df}=4$ Table value $\times 2$ at 0.05 level $=9.488$

Table 1.10 shows that the calculated $x^{2}$ value was found to be 126.2 , which is greater than the table value at 0.05 level. Hence, the statement is accepted.

Table 1.11: Poverty is promoting self-hurt in the students

\begin{tabular}{cccccccc}
\hline & SA & A & UD & DA & SD & Total & $X^{2}$ \\
\hline Responses & 01 & 49 & - & - & - & 50 & \multirow{2}{*}{$190.2^{*}$} \\
Percentage & 02 & 98 & - & - & - & 100 & \\
\hline
\end{tabular}

* Significance $\mathrm{df}=4$ Table value $\times 2$ at 0.05 level $=9.488$

Table 1.11 shows that the calculated $X^{2}$ value was found to be 190.2 which is greater than the table value at 0.05 level. Hence, the statement is accepted.

Table 1.12: Poverty is promoting misconduct in the students

\begin{tabular}{cccccccc}
\hline & SA & A & UD & DA & SD & Total & $X^{2}$ \\
\hline Responses & 48 & 02 & - & - & - & & $180.8^{*}$ \\
Percentage & 96 & 04 & & & & 100 & 180
\end{tabular}

* Significance $\mathrm{df}=4$ Table value $\mathrm{x2at} 0.05$ level $=9.488$

Table 1.12 shows that the calculated $x^{2}$ value was found to be 982.5 , which is greater than the table value at 0.05 level. Hence, the statement is accepted.

\section{Responses of Interview Questions}

A structured interview was conducted with parents of the challenging behavior students. The number of parents was 40 belonging to urban areas of Islamabad. The response was received from all the parents. All the parents were approached by the researcher through their sons (9th class students). Most of the parents were literate/educated (Secondary School Level to Graduate level qualification). Before interview; the parents were briefed by the researcher about the study. Interview was conducted in Urdu language (National language of Pakistan). All the parents of the identified students provided the response with fully satisfaction, truth and confidence. The responses of parents were about the followings:

1. Poverty is affecting behavior of students.

2. Poverty is promoting challenging behavior in students.

3. Poverty is promoting irresponsibility in the students

4. Poverty is promoting authoritative attitude in the students

5. Poverty is promoting disappointment in the students

6. Poverty is promoting loneliness in the students

7. Poverty is promoting theft in the students

8. Poverty is promoting drug addiction in the students

9. Poverty is promoting cheating in the students

10. Poverty is promoting hurting others in the students

11. Poverty is promoting self-hurt in the students

12. Poverty is promoting misconduct in the students 
Theme Analysis of Interview Questions:

\begin{tabular}{clc}
\hline S. No & Theme & Majority responses (Accepted/Rejected) \\
\hline 1. & Poverty is affecting behavior of students & accepted \\
2. & Poverty is promoting challenging behavior in students & accepted \\
3. & Poverty is promoting irresponsibility in the students & accepted \\
4. & Poverty is promoting authoritative attitude in the students & accepted \\
5. & Poverty is promoting disappointment in the students & accepted \\
6. & Poverty is promoting loneliness in the students & accepted \\
7. & Poverty is promoting theft in the students & accepted \\
8. & Parental causes of challenging behavior & accepted \\
9. & Poverty is promoting cheating in the students & accepted \\
10. & Poverty is promoting hurting others in the students & accepted \\
11. & Poverty is promoting self-hurt in the students & accepted \\
12. & Poverty is promoting misconduct in the students & accepted \\
\hline
\end{tabular}

The responses of 40 parents proved that challenging behavior was present in their sons as their parents were dissatisfied with their behavior. Most of the parents informed that they were not in position to provide basic need well. Most of the parents were in opinion that illiteracy of parents and de-moralized environment were the major causes of challenging behavior in the students. Most of the parents were in opinion that they received complaints against their sons. Most of the parents were agreed on the symptoms of challenging behavior to be found in their sons. The responses of parents proved that they had sufficient knowledge of challenging behavior. It is also proved that teachers' identification of students with challenging behavior was true.

\section{Findings of the Study}

1. Poverty is promoting challenging behavior in students.

2. Poverty is promoting irresponsibility in the students

3. Poverty is promoting authoritative attitude in the students

4. Poverty is promoting disappointment in the students

5. Poverty is promoting loneliness in the students

6. Poverty is promoting theft in the students

7. Poverty is promoting drug addiction in the students

8. Poverty is promoting cheating in the students

9. Poverty is promoting hurting others in the students

10. Poverty is promoting self-hurt in the students

11. Poverty is promoting misconduct in the students

\section{Conclusion}

Qualitative and quantitative findings of the study represent that poverty and challenging behavior are correlated with each other. Poverty and challenging behavior are directly proportional to each other. When poverty is increased then challenging behavior is increased and when poverty is decreased then challenging behavior is decreased.

\section{References}

Abramson, L.Y., Seligman, M.E.P., \& Teasdale, J.D. (1994).Learned helplessness in humans: Critique and reformulation. Journal of Educational Psychology

Agras, W.S. (1985). Panic: Facing fears, phobias, and anxiety. N:W.H. Freeman \&Co. Agras, W.S., Sylvester, D. \& Oliveau, D. (1999). The affects of challenging behavior of secondary school students on school discipline. Journal of Educational Psychology

Akhtar, S. Wig, N.N. Verma, V.K., Pershad, D., \&Verma, S.K. (2004).A analysis of symptoms of challenging behavior in students. British Journal of Educational Psychology

Baumrind, D. (1966). Effects of authoritative parental control on child behavior. Child Development

Brenner, V., \& Fox, R. A. (1998). Parental discipline and behavior problems in young children. The Journal of Genetic Psychology

Best Practice Behavior Management (2007) Post Primary Teachers' Association; Otago, New Zealand.

Creswell, John W. (2003).Research Design, Qualitative, Quantitative, and Mix methods Approaches. California. Sage Publications Dawn, M. (2003) "Challenging behaviour: the perceptions of teachers of children and young people with severe learning disabilities". 
Journal of Research in Special Education Needs

Doss, S. \& Reichle, J. (1991). Replacing excess behavior with an initial communicative repertoire. In J.Reichle, J. York, \& J. Sigafoos, (Eds.), Implementing Augmentative and Alternative Communication (pp. 215-237). Baltimore: Paul H. Brookes.

Ghazi (2013) "Types and Causes of Students' Disruptive Behavior in Classroom at Secondary Level in Khyber Pakhtunkhwa, Pakistan" The Express Tribune, June 15th, 2013.

McMahon, F.B; McMahon J.W.(2006). Challenging Behavior of Students. University of Illinois: The Dorsey Press.

Murtaza, A.(2011).Corporal punishment a major reason for school dropouts. Asian Human Rights Commission Naqvi,S(2011). Child Sexual Abuse-A barbaric Savagery in Pakistan. Students of Pakistan

Managing Challenging Behavior: Guidelines for Teachers. Irish National Teachers Organization; November 2004

Best Practice Behavior Management (2004) Post Primary Teachers' Association; Otago, New Zealand. 